\title{
The physical characteristics of ice cream with the addition of goat bone gelatine as a stabilizer
}

\author{
Ria Dewi Andriani ${ }^{1, *}$, Premy Puspitawati Rahayu ${ }^{1}$, Mustakim $^{1}$, Mulia Winirsya Apriliyani ${ }^{1}$, \\ Manik Eirry Sawitri ${ }^{1}$, Abdul Manab ${ }^{1}$ and Sopi Sopiatun $\mathrm{Nida}^{2}$ \\ ${ }^{1}$ Animal Product Technology Department, Faculty of Animal Science, Universitas Brawijaya, Jl. \\ Veteran Malang, 65145, East Java, Indonesia \\ ${ }^{2}$ Student of the Faculty of Animal Science, Universitas Brawijaya, Jl. Veteran Malang, 65145, East \\ Java, Indonesia
}

\begin{abstract}
The purpose of this study is to determine the appropriate concentration of gelatin bone goat to the physical quality of the ice cream. The good of ice cream making can be examined from their physical properties including overrun, viscosity, melting point, and emulsion stability. This study employs a complete random design (CRD) with the treatment that is given including, P0 (controlled), P1 (the use of goat bone gelatin by $0.5 \%$ ), P2 (the use of goat bone gelatin by $1 \%$ ), P3 (the use of goat bone gelatin by $1.5 \%$ ). The observed variable is overrun, viscosity, melting point, and emulsion stability. The results show that ice cream with the addition of a goat bone gelatin stabilizer as much as $1.5 \%$ produces ice cream with the best quality with an average value of $65.11 \%$ overrun, the viscosity to $84.57 \mathrm{cP}, 35.31$ minutes $/ 50 \mathrm{~g}$ melting point and $84.03 \%$ of emulsion stability.
\end{abstract}

\section{Introduction}

Ice cream is one among other various kinds of dairy products that is enjoyed by all classes of society and most favoured compared to other kinds of dairy products such as yogurt, cheese and kefir. The consumption of ice cream that increases gradually from time to time is characterized by the addition of variants and amounts of ice cream in the market [1,2]. Violisa et al. (2012) reported that the consumption of ice cream in Indonesia ranges from $0.5 \mathrm{~L} / \mathrm{person} /$ year with the potential market for ice cream in Indonesia reaching 110 million liters/year. However, the number hardly amounted to 40 million litres/year [3].

Ice cream is a type of frozen shaped food made by freezing a mixture of dairy products, sugars, stabilizers, emulsifiers and other ingredients that have been pasteurized and homogenized [4,5]. The manufacturing process of ice cream requires a stabilizer to maintain the emulsion and to improve the smooth texture of the ice cream. Bahramparvar and Therani (2011) reported that stabilizer serves to store the water inside the ice cream in order to reduce the crystallization of ice [6]. El Aziz et al. (2015) adds that the purpose of using a stabilizer is to produce a soft texture, reducing the crystalline lactose and ice

* Corresponding author: riaandriani@ub.ac.id 
crystals during storage, resisting the flow, forming cohesion in the product, and increasing the viscosity [7]. The stabilizer can bind water in the state where it is not frozen, therefore capable of reducing the formation of ice crystals.

Stabilizing substances that are often used are gelatin. The excess gelatin in the manufacturing of ice cream can suppress the formation of ice crystals perfectly and produce a smoother texture for the ice cream [8]. Generally, the use of gelatin in Indonesia is largely obtained by importing from other Countries such as America. The materials to manufacture gelatin are obtained from pigs and cattle, which still raises concerns among the religious communities in Indonesia. A way to solve this is to use gelatin obtained from goats. The use of gelatin as a stabilizer in the manufacturing of ice cream produces a higher average of overrun score, texture, taste, scent and an overall reception compared to the use of CMC (carboxymethyl cellulose) stabilizers [9,10,11]. Based on the description above, a study on the use of goat bone gelatin as a stabilizing material or stabilizer for good quality ice cream is carried out.

\section{Materials and methods}

\subsection{Materials}

The raw materials used in the manufacturing of this ice cream include: fresh milk as the basic material obtained from KUD Sae Pujon, sugar, skimmed milk, creamer and quick emulsifier obtained from Primarasa Store, Dinoyo, Malang. Whereas the goat bone gelatin as a stabilizer was obtained from the Laboratory of Animal Product Technology Universitas Brawijaya.

\subsection{Methods}

\section{Manufacturing of the Ice Cream}

The ice cream making process includes several stages, namely the mixing of the ingredients, pasteurizing, homogenizing, aging, freezing and agitation, packaging, freezing and storing [12]. The manufacturing process carried out in this study are as follows: Manufacturing of ice cream including several stages, namely, the process of mixing with a water temperature of $40-48{ }^{\circ} \mathrm{C}$ which is used to prevent clumps in the milk, as well as to dissolve the sugar and gelatin. Pasteurization to a temperature of $80{ }^{\circ} \mathrm{C}$ for 15 -minute serves to kill the pathogenic microorganisms. Homogenization serves to homogenize the fat globule and to accelerate the aeration. The cooling of the ice cream dough before aging serves to prevent heat shock. Aging serves to densify the fat, increase the viscosity of the mixture from initiating the formation of gel on the gelatin, and entrap water from the gelatin. Foaming with an ice cream maker to contain the air in the gelatin gel shrinks the size of ice crystals and dismantles the globular fat. Densifying for 24 hours at $15{ }^{\circ} \mathrm{C}$ serves to maintain the robust shape of the ice cream.

\section{Experimental Design and Data Analysis}

The method applied in this study is a experimental laboratory with four treatments and four replications, including:

P0 : Manufacturing ice cream without the use of goat bone gelatin (control) 
P1 : Manufacturing ice cream with the use of $0.5 \% \mathrm{w} / \mathrm{v}$ of goat bone gelatin

P2 : Manufacturing ice cream with the use of $1 \% \mathrm{w} / \mathrm{v}$ goat bone gelatin

P3 : Manufacturing ice cream with the use of $1.5 \% \mathrm{w} / \mathrm{v}$ goat bone gelatin

The parameters tested including overrun [13]; the viscosity used from Brook Field Viscometer DVII model following the procedure of [14]; melting point [15] and emulsion stability $[14,16]$. The data obtained were tabulated and analyzed using analysis of variance (ANOVA) using the Microsoft Excel 2007 program. If the results obtained is different then it will proceed with the Distance Test of Duncan's Multiple (UJBD) to see the difference from each treatment.

\section{Results and discussion}

\subsection{Overrun}

Results from UJBD shows that the influence of using goat bone gelatin towards overrun ice cream on each of the different treatments was highly significant $(\mathrm{p}<0.01)$. The results of the overrun ice cream with goat bone gelatin stabilizer obtained an average between 65.12$87.19 \%$ (Table 1). The test results showed that the higher the concentration of the stabilizer will decrease the value of the overrun, for the reason that the higher the concentration of the gelatin used, the dough becomes more viscous and the surface tension reaches higher, therefore, the product hardly inflates. Hartatie (2011) [9]; Ntau (2021) [17] reported that a mixture of ice cream dough should not be too thick because it will perplex the inflating process, therefore minimizing the overrun. On the inflating process of the ice cream volume, the mixing process can cause an effect resulting in a spread in the fat components and forming a web around the air that binds water. The mixing process is done at low temperature (under $10^{\circ} \mathrm{C}$ ) to form crystallization of the fat. The process of crystallization of the fat is essential to form fat globules into three-dimensional structures that can entrap water and air, resulting in the inflating volume of the ice cream [18]. If the mixing is performed at a high temperature, then the size of the fat globule will enlarge and be unable to form three-dimensional structures [19]. In the manufacturing of ice cream, the method applied also affects overrun. The method applied in this study is the conventional method, due to the reason that conventional methods do not require stirring and cooling that are done simultaneously, instead done alternately i.e. mixing/ homogenization, cooling, stirring and then returning to cooling. This process and the changes of temperature allows the air entrapped in the dough to become contingent on the speed, stirring duration, and temperature change, in result affecting the inflate or overrun of ice cream produced.

Table 1. The average value of the overrun, viscosity, melting power and emulsion stability

\begin{tabular}{|c|c|c|c|c|}
\hline Treatment & $\begin{array}{c}\text { Overrun } \\
(\%)\end{array}$ & Viscosity (Cp) & $\begin{array}{c}\text { Melting Point } \\
(\text { minutes/50 g) }\end{array}$ & $\begin{array}{c}\text { Emulsion Stability } \\
(\%)\end{array}$ \\
\hline P0 & $\begin{array}{c}87.19 \pm 0.1 \\
0^{\mathrm{d}}\end{array}$ & $74.29 \pm 0.73^{\mathrm{a}}$ & $26.90 \pm 0.64^{\mathrm{a}}$ & $76.54 \pm 0.89^{\mathrm{a}}$ \\
\hline P1 & $\begin{array}{c}84.85 \pm 0.3 \\
2^{\mathrm{c}}\end{array}$ & $79.56 \pm 1.56^{\mathrm{b}}$ & $30.82 \pm 0.67^{\mathrm{b}}$ & $80.56 \pm 0.47^{\mathrm{b}}$ \\
\hline P2 & $\begin{array}{c}72.61 \pm 0.2 \\
0^{\mathrm{b}}\end{array}$ & $82.52 \pm 0.98^{\mathrm{c}}$ & $32.96 \pm 0.51^{\mathrm{c}}$ & $81.18 \pm 0.19^{\mathrm{c}}$ \\
\hline P3 & $\begin{array}{c}65.12 \pm 0.7 \\
5^{\mathrm{a}}\end{array}$ & $84.51 \pm 0.56^{\mathrm{d}}$ & $35.26 \pm 0.12^{\mathrm{d}}$ & $84.03 \pm 0.33^{\mathrm{d}}$ \\
\hline
\end{tabular}




\subsection{Viscosity}

The use of goat bone gelatin provides a significant different $(p<0.01)$ that influences towards the viscosity of the ice cream. The average value of viscosity of the ice cream is $74.29-84.51 \mathrm{cP}$ (Table 1). The appropriate value of ice cream ranges between 50-300 $\mathrm{cP}$. The largest average value of the viscosity obtained from the P3 treatment of $84.51 \mathrm{cP}$ with the use of goat bone gelatin is as much as $1.5 \%$. This is due to the increasing amount of used percentage of goat bone gelatin, which is known to bind water. Marshall and Arbuckle (2000); Syed and Shah (2016) stated that an increase in the viscosity of ice cream is due to the process of homogenization and the presence of a stabilizer added [19, 20]. Goat bone gelatin has the ability to bind water so that the initial water moving out before the molecules of the material become entrapped, therefore the space between particles narrows and eventually lead to an increase in viscosity. This aligns with Marshall and Arbuckle (2000) who states that the increase in viscosity can be caused by particles suspended in the cream dough, such as fiber, water, and protein components associated with the stabilizing materials [20].

\subsection{Melting Point}

The use of goat bone gelatin provides a significant difference that $(\mathrm{p}<0.01)$ towards the melting point of ice cream. The average of melting point of the ice cream using goat bone gelatin is $26.90-35.26$ minutes $/ 50 \mathrm{~g}$. The ice cream produced in this study is considered well made since it has the average melting speed value above 25 minutes. This finding in line with Widiantoko and Yunianta (2014) that states ice cream with good quality has a speed of melt in between 25-30 minutes [22]. The longest average melting time resulted from the $\mathrm{P} 3$ treatment, with 35.26 minutes $/ 50 \mathrm{~g}$ use of goat bone gelatin as much as $1.5 \%$. This is due to the use of goat bone gelatin that affects the strength of the ice cream's body, resulting in it to be fragile and less robust. This is in accordance with the statement made by Arachchi et al. (2015) which states that the quick melting time of ice cream is shown by the body of the ice cream that is fragile and less robust. The use of stabilizer can also slow down the melting of ice cream when served [23]. The use of goat bone gelatin can bind water in the ice cream dough, therefore it is believed that the ice crystals formed do not melt quickly because goat bone gelatin increases the viscosity of the product. This aligns with Karaman et al. (2014) who states that ice cream with a high viscosity coefficient value will have a greater resistance from melting [24]. The overrun value will affect the density of the ice cream. High overrun produces a larger amount of air cavity and the ice cream that is formed is fragile and will melt quickly.

\subsection{Emulsion Stability}

The use of goat bone gelatin showed the significant difference $(\mathrm{p}<0.05)$ on the emulsion stability of ice cream. The average stability of the emulsion ice cream with the use of goat bone gelatin is $76.54-84.03 \%$ (Table 1). The results show that the higher concentration of the gelatin, therefore the higher the stability of the emulsion. Gelatin can increase the stability of the ice cream. The stability of the emulsion shows the resistance of the ice cream dough towards the separation of milk proteins and milk fat. One way to maintain the stability of the ice cream is to increase its viscosity through the addition of stabilizer into the ice cream mix. Gelatin is a protein type of stabilizer that is also a material for gel making, given that proteins are polymers of amino acids. Amino acids are hydrophilic and hydrophobic. In other words, amino acids can interact with water and some others can 
interact with oil. If protein is dissolved into the water phase, the hydrophobic part (side chain) will have an affinity to interact with the oil phase part of the interface, therefore droplets of oil can be adjacent to the water phase. This interaction will form hydrogen bonding between molecules of water with gelatin or bonds among gelatin molecules, which can then form a web and entrap the liquid to acquire an elastic and solid phase $[25,26]$

\section{Conclusion}

This finding of this study can be concluded that ice cream with the addition of a stabilizer from goat bone gelatine as much as $1.5 \%$ produces ice cream with the best physical quality, with the value of the average overrun of $65.11 \%$, the viscosity to $84.57 \mathrm{cP}$, melting point of 35.31 minutes $/ 50 \mathrm{~g}$, and the emulsion stability of $84.03 \%$, respectively.

\section{References}

1. U. Sarofa, F. Rosida Dedin, Khadik, Jurnal Rekapangan, 8, 2-3 (2014)

2. QA, Syed, S, Anwar, R,Shukat J Nutr Health Food Eng, 8, 422-435 (2018)

3. Violisa, A., A. Nyoto dan N. Nurjanah, Teknologi dan Kejuruan, 35, 103-114 (2012)

4. S.J. Yeon, J.H, Kim., G.E, Hong., W. Park., S.K, Kim., H.G, Seo., and C.H. Lee, Korean Journal for Food Science of Animal Resources, 37, 38-43 (2018)

5. G.S. Darma. D. Puspitasari, E. Noerhartati, Media Teknologi dan Manajemen Agroindustri, 1, 46-53 (2013)

6. M. Bahramparvar, and M.M.Tehrani, Food Reviews International. 27, 389-407 (2011)

7. M.A. El-Aziz, H.F, Haggag., M.M. Kaluobi., L.K. Hassan., M.M. El-Sayed., and A.F. Sayed, International Journal of Dairy Science. 10, 160-172 (2015)

8. D. Hastuti, dan I. Sumpe, Jurnal Medagro, 3, 39-48 (2007)

9. S. E, Hartatie, Jurnal Gamma, 7, 21-22 (2011)

10. R. Juliasti, A. M. Legowo dan Y. B. Pramono, Jurnal Aplikasi Teknologi Pangan. 4, 5-46 (2015)

11. N. Guzeler, L. Dogdu., M. Kalender., and C. Ozbek, $2^{\text {nd }}$ International Energy and Engineering Conference. Gaziantep, Turkey (2017)

12. M.A. Moulina, AGRITEPA. 3, 32-45 (2016)

13. Achmad, F., Nurwantoro dan S. Mulyani, Animal Agricultur Journal, 65-76 (2012)

14. AOAC. Official Methods of Analysis Assosiation of Official Analytical Chemist (Washington D.C, 2005)

15. A.M. Roland, L. G. Philips, and K. J. Boor, J. Dairy Science. 82, 2094-2100 (1999)

16. Priastami, C.S. Karagenan Sebagai Bahan Penstabil Pada Proses Pembuatan Melorin. Skripsi, Departemen Teknologi Hasil Perairan Fakultas Perikanan dan Ilmu Kelautan Institute Pertanian Bogor. (2011)

17. Ntau, E., G.S.S. Djarkasa., dan L.E.Lalujan, Sam Ratulangi Journal of Food Research. 1, $10-19,(2021)$

18. M.C. Milliatti, and S.C.D.S. Lannes, Food Science and Technology. 38, 733-739 (2018)

19. H. D. Goff, dan R.W. Hartel, Ice Cream Seventh Edition (Springer Science plus Bussines Media, New York, 2013)

20. R, Marshall, and W. S. Arbuckle. Ice Cream (aspen Publishers, Maryland, 2000)

21. QA. Syed, and M. S. U. Shah, MOJ Food Processing and Technology. 3, 246-252, (2016) 
22. R. K. Widiantoko, dan Yunianta, Jurnal Pangan dan Agroindustri. 2, 54-66, (2014)

23. Arachchi, J. Brasathe., A. Weerakoon, Proceedings of the Faculty of Agriculture Undergraduate Research Symposium, (2015)

24. S. Karaman, O.S. Toker., F. Yuksel., M.Cam., A. Kayacier., and M. Dogan, J. Dairy Sci. 97, 97-110, (2014)

25. S.A. Salem, M. Fardous, and M.G.H, El-Rashody, Food and Nutrition Sciences, 8, 551-564 (2017)

26. D. Fatimah, Jurnal Kimia, $1: 12-13$, (2009) 